\title{
PROGRAM “MENCIPTAKAN KELAS BERSAHABAT" DAN PENGELOLAAN KELAS
}

\section{"CREATING FRIENDLY CLASSROOM" PROGRAMME AND CLASSROOM MANAGEMENT}

\author{
Amitya Kumara \\ Birlanti Novita Sari \\ Dinni Asih Febriyanti \\ Husna Ika Putri Sari \\ Fakultas Psikologi Unversitas Gadjah Mada Yogyakarta \\ E-mail: amikumara@yahoo.com
}

\begin{abstract}
This study aims to determine the effect of "Creating Friendly Classroom Programme" on classroom management and upgrading of teacher competence in building a safe and comfortable classroom, as well as the effect of the programme implementation in reducing aggression and increasing prosocial behaviour among kindergarten's students. "Creating Friendly Classroom" Programme is a bullying preention adapted from "The Anti-Bullying and Teasing Book for Preschool Classroom". Subjects were teachers and students of two kindergartens in Sleman. The study used quasi experimental design with untreated control group pre-test and pos-test. The teachers was measured by using classroom management scale, classroom management observational form, teacher performance observational form, scale of teacher's knowledge and understanding. The students was measured by using aggressivity observational form and pro-social behaviour observational form. Preface the programme started, teachers was given training about the programme and then applied it to their students. The result showed the teacher's classroom management and teachers competence in building a safe and comfortable classroom ncreased after the training. Then the implementation of programme by tacher can reduce students aggression and increase students prosocial's behaviour.
\end{abstract}

Keywords: Classroom Management, Bullying, Kindergarten 


\section{ABSTRAK}

Penelitian ini bertujuan mengetahui pengaruh pelatihan Program Menciptakan Kelas Bersahabat terhadap peningkatan kemampuan pengelolaan kelas dan kompetensi guru dalam membangun kelas yang aman dan nyaman, serta pengaruh penerapan program tersebut terhadap penurunan agresivitas dan peningkatan prososial pada siswa Taman Kanak-Kanak (TK). Program "Menciptakan Kelas Bersahabat" merupakan upaya pencegahan bullying yang diadaptasi dari The Anti Bullying and Teasing Program for Preschool Classroom. Subjek penelitian adalah guru dan siswa di dua TK di Sleman. Penelitian menggunakan desain eksperimen kuasi untreated control group with pre-test and post-test. Kondisi pre dan post guru diukur menggunakan skala pengelolaan kelas, panduan observasi pengelolaan kelas, panduan observasi performa guru, skala pengetahuan dan pemahaman guru, serta checklist adherence. Sedangkan dalam pengukuran terhadap siswa digunakan panduan observasi perilaku agresif dan panduan observasi perilaku pro-sosial. Sebelum program dimulai, guru pada kelompok eksperimen diberi pelatihan mengenai konsep dan prosedur penerapan program untuk kemudian diterapkan pada para siswa. Hasil penelitian menunjukkan kemampuan guru dalam mengelola kelas dan kompetensi guru dalam membangun kelas yang aman dan nyaman meningkat setelah pelatihan. Selanjutnya, penerapan program oleh guru dapat menurunkan agresivitas siswa dan meningkatkan prososial siswa.

Kata Kunci: Pengelolaan Kelas, Bullying, Taman Kanak-Kanak

Data di lapangan menyebutkan bahwa banyak terjadi perilaku agresif yang muncul di Taman Kanak-kanak (TK). Sebuah survei menyebutkan bahwa sebagian besar dari 123 guru di 20 TK melaporkan adanya perilaku agresif yang muncul. Perilakuperilaku agresif yang dimaksud antara lain adalah (a) agresivitas verbal, yaitu menertawakan teman sebanyak 88,62\%, mengatakan hal-hal yang jahat kepada teman (34,92\%), dan membungkam teman $(16,26 \%)$, (b) agresivitas terkait barang kepemilikan teman, yaitu merampas barang milik teman (45,53\%), menghancurkan barang milik teman $(17,89 \%)$, dan menyembunyikan barang milik teman (50,41\%), (c) agresivitas fisik, yaitu menarik rambut teman $(34,15 \%)$, memukul teman $(73,17 \%)$, menggigit teman $(19,51 \%)$, dan menendang teman $(63,41 \%)$, serta (d) agresivitas psikologis, yaitu tidak mengizinkan teman untuk bergabung $(64,23 \%)$, dan tidak mengizinkan teman untuk duduk di dekatnya (60,16\%). Bahkan, 48,78 \% dari guru tersebut melaporkan bahwa ada siswa tertentu di kelasnya yang seringkali menjadi korban perilaku agresif teman-temannya (Kumara dkk, 2010a). Adanya siswa tertentu yang seringkali menjadi korban adalah salah satu indikasi perilaku bullying.

Wujud atau bentuk perilaku agresif terdiri atas perilaku agresif fisik seperti memukul dan menendang 
yang dapat mengakibatkan luka pada badan, perilaku agresif verbal seperti membentak, mengejek, atau memberi julukan yang melukai perasaan orang lain, serta perilaku yang terkait dengan merusak pergaulan seseorang seperti menyebarkan rumor, mengabaikan dan tidak mengijinkan seseorang bergabung dalam pertemanan (Papalia dkk, 2004; Keenan \& Evans, 2009). Bullying adalah sub bagian dari perilaku agresif yang memiliki dua ciri tambahan, yaitu (1) adanya ketidakseimbangan kekuatan, di mana perilaku agresif dilakukan oleh pihak yang lebih kuat kepada pihak yang lebih lemah, serta (2) adanya pengulangan perilaku (Olweus, 1993; Perren, 2000). Bentuk perilaku bullying serupa dengan bentuk perilaku agresif yang terdiri atas perilaku fisik seperti memukul dan menendang yang dapat melukai badan; serta kekerasan psikologis dalam interaksi sosial seperti menyebarkan kejelekan seseorang dan mengasingkan seseorang dari pergaulan sosial (Ormrod, 2006). Menurut Rigby (Perren, 2000), bullying terdiri dari dua bentuk, yaitu bullying langsung (direct) dan bullying tidak langsung (indirect).

Selama ini guru mengatasi permasalahan yang terjadi di kelas dengan cara mengubah perilaku anak melalui hadiah dan hukuman. Padahal ada pendekatan lain yang lebih efektif dalam mengubah perilaku anak dan mampu menyentuh kurang lebih 85\% dari seluruh anak yang berada di dalam suatu lingkungan. Pendekatan tersebut adalah pendekatan konstruksi sosial. Jika pendekatan perlakuan memandang pengajaran sebagai pembentukan perilaku di mana perilaku dan belajar siswa dipengaruhi oleh penguatan, maka pendekatan konstruksi sosial memandang pengajaran sebagai stimulasi pemaknaan (meaning making) di mana proses belajar anak dipengaruhi oleh proses sosial yang muncul pada aktivitas bersama yang dilakukan secara kolektif yang ada di kelas (Kumara dkk, 2010b). Ada empat faktor yang melatarbelakangi minat terhadap pendekatan konstruksi sosial atas pendekatan perilaku (Palincsar, 1998), yaitu (1) distribusi kerja kognitif, (2) pengajaran timbal balik (reciprocal teaching), (3) menyuarakan apa yang dipikirkan (think alouds), serta (4) pembahasaan pikiran (language production).

Pendekatan konstruksi sosial dalam membentuk perilaku anak di sekolah sangat berkaitan dengan kemampuan guru untuk mengelola situasi kelas. Pengelolaan kelas didefinisikan sebagai suatu upaya guru untuk menciptakan lingkungan belajaryang sehat dan produktif, yaitu memiliki interaksi sosial yang positif seperti peduli dan saling percaya (Eggen \& Kauchak, 2010), menciptakan keterlibatan siswa secara aktif belajar, menumbuhkan motivasi dalam diri siswa (Burden 2003; Woolfolk, 2004), menumbuhkan tanggung jawab belajar, serta memaksimalkan waktu dan kesempatan untuk belajar (Eggen \& Kauchak, 2010). Menurut Burden (2003), 
ada tujuh area tanggung jawab yang harus dikuasai oleh guru sebagai manajer kelas yang efektif. Ketujuh area tersebut adalah (1) memilih suatu model filosofis dari mengelola kelas dan kedisiplinan, (2) mengatur lingkungan fisik, mengatur perilaku siswa, (4) menciptakan lingkungan belajar yang saling mendukung dan saling menghormati, (5) mengatur dan memfasilitasi instruksi pengajaran, menciptakan lingkungan kelas yang aman dan nyaman, dan (7) berinteraksi dengan rekan guru lain, orangtua, dan pihak lain untuk mencapai tujuan pembelajaran.

Sebagian besar guru yang sudah berpengalaman berpendapat bahwa program sebaik apapun dan sudah dikuasai oleh guru namun tidak dibarengi dengan keterampilan guru dalam mengelola kelas, maka program tersebut akan siasia (Moore, 2003). Jika guru kurang mampu mengelola kelas, tidak tertutup kemungkinan kelas menjadi chaos misalnya terjadi kekerasan di dalam kelas, baik yang dilakukan oleh sesama siswa, maupun guru dengan siswa. Kemampuan guru untuk mengelola beragam sikap, kebutuhan siswa, motivasi siswa dengan menggunakan teknik sehingga menjadi kelas yang efektif merupakan aspek terpenting dari kesuksesan sebuah kelas.

Salah satu program yang mampu mewujudkan tujuan pendekatan kontruksi sosial adalah The Anti-Bullying and Teasing Program for Preschool Classroom yang disusun oleh Sprung, Froschl, dan Hinitz (2005). Program ini banyak memodifikasi aspek mikrosistem lingkungan kelas, mulai dari aktivitasaktivitas kelas, peran guru dalam kelas, hingga pola interaksi siswa. Menciptakan lingkungan kelas yang saling peduli dianggap dapat mengurangi kebutuhan anak untuk unjuk diri lewat perilaku negatif seperti mengganggu (bullying) dan menggoda (teasing). Peran guru dalam mencegah terjadinya perilaku bullying dalam kelas dikuatkan dengan adanya enam rekomendasi strategi, yang dapat memudahkan guru untuk menyelesaikan konflik yang terjadi antar siswa, menangani anak yang sedang emosi, mengajarkan nilai-nilai, menertibkan area bermain, serta memancing diskusi. Terakhir, teladan guru untuk memperhatikan dan membantu sesama direkomendasikan untuk mencontohkan pola perilaku yang sehat pada anak untuk ditiru.

The Anti-Bullying and Teasing Program for Preschool Classroom merupakan sebuah program berkelanjutan yang terdiri atas empat tema utama, yaitu komunitas, perasaan, persahabatan, serta teasing dan bullying. Tema yang akan digunakan dalam penelitian ini adalah tema komunitas sebagai tema pembuka yang menjadi dasar penerapan tematema selanjutnya. Tema komunitas berfokus pada tujuan untuk mencegah dan menghambat munculnya perilakuperilaku agresif anak dengan cara menciptakan lingkungan yang ramah, penuh penerimaan dan saling menghargai melalui pelaksanaan 10 aktivitas kelas 
guna menciptakan lingkungan kelas yang bersahabat. Oleh karena itu, judul program disesuaikan dengan tujuan tema tersebut, yaitu "Program Menciptakan Kelas Bersahabat" (selanjutnya disebut Program MKB).

Selain bertujuan untuk menghambat terjadinya perilaku agresif siswa TK kepada temannya, aktivitas-aktivitas kelas yang direkomendasikan untuk diterapkan dalam program juga ditujukan untuk merangsang terbentuknya perilaku prososial pada siswa TK. Perilaku prososial adalah perilaku yang memberikan manfaat kepada orang lain (Berns, 2007). Perilaku prososial memiliki empat tipe, yaitu perilaku prososial altruistik (menolong secara sukarela karena rasa empati dan prinsip yang dimiliki), perilaku prososial kepatuhan (menolong orang lain sebagai respon verbal atau nonverbal), perilaku prososial emosional (menolong orang lain karena situasi emosional, seperti menolong orang yang kesakitan karena terluka), serta perilaku prososial publik (perilaku prososial yang dilakukan di depan banyak orang) (Carlo \& Randall, 2002). Mengajarkan anak untuk berperilaku prososial dapat meningkatkan kompetensi sosial dan mengurangi kemungkinan mereka melakukan tindakan kekerasan yang mengarah pada perilaku bullying, seperti saling tolong menolong, bertindak sesuai aturan, penuh penerimaan, saling berbagi, hingga kerja sama pada anak.

Kesepuluh aktivitas dalam tema komunitas beorientasi pada tiga subtujuan, yaitu (1) mengenalkan pada anak konsep "keluarga" di dalam kelas sehinga anak menyadari bahwa kelas mereka juga merupakan keluarga mereka selain dari keluarga mereka di rumah, (2) mengembangkan sikap menghargai perbedaan, yang dapat membantu anak menjadi anggota "keluarga" yang penuh penerimaan dan pemahaman terhadap perbedaan yang ada dalam komunitas sekolah mereka, dan (3) membantu anak mengeksplorasi konsep "persamaan dan perbedaan" lewat cerita dan diskusi tentang ciri fisik yang dimiliki manusia, struktur keluarga, serta makanan favorit masing-masing, sehingga anak memiliki pemahaman mengenai persamaanpersamaan dan menghargai perbedaanperbedaan yang dimiliki manusia. Dalam program "MKB", beberapa aktivitas yang berada dalam topik yang sama disatukan menjadi satu kali pelaksanaan, sehingga sepuluh aktivitas yang ada dipadatkan menjadi tujuh aktivitas. Hal ini menyesuaikan dengan kurikulum sekolah dan ketersediaan waktu dari sekolah tempat penelitian.

Penelitian ini dilakukan untuk menguji efektivitas "Program MKB" untuk meningkatkan keterampilan guru mengelola kelas di TK. Program ini memiliki tiga karakteristik yang menjadi nilai penting untuk diterapkan oleh guru di TK dalam mencegah terjadinya bullying di kelas, yaitu (1) bersifat preventif sehingga dapat diterapkan secara luas, (2) berfokus pada aktivitas-aktivitas kelas yang dapat 
menumbuhkan iklim positif di kelas, salah satu faktor penting yang memengaruhi bullying (Barboza, Schiamberg, Oehmke, Korzeniewski, Post, \& Heraux, 2009), serta (3) setting penerapan program adalah kelas TK sehingga perilaku bullying dapat dicegah sedini mungkin.

Penerapan "Program MKB" didahului dengan memberikan pelatihan kepada para guru mengenai konsep dasar (latar belakang, dasar pemikiran, nilai-nilai yang terkandung dalam program) dan prosedur implementasi program kepada para siswa di kelas. Pelatihan bertujuan untuk meningkatkan kompetensi guru dalam menciptakan kelas yang aman dan nyaman. Kompetensi guru dalam membangun kelas yang aman dan nyaman didefinisikan sebagai seperangkat kemampuan dan keterampilan guru dalam melaksanakan tugas pembelajaran di kelas yang ditunjukkan dengan perilaku kompeten berupa menciptakan kondisi kelas di mana siswa merasa aman dalam mengikuti kegiatan belajar di kelas (Burden, 2003; Cubcuku, 2010; Ormrod, 2006).

Peningkatan kompetensi guru dalam membangun kelas yang aman dan nyaman merupakan salah satu indikasi keberhasilan peningkatan kemampuan guru dalam mengelola kelas. Indikasi lain tercermin pada penurunan perilaku agresif yang disertai peningkatan perilaku prososial siswa TK setelah guru menerapkan "Program MKB" di kelas.
Berdasarkan penjelasan di atas, dapat dibuat hipotesis mayor dalam penelitian ini, yaitu ada pengaruh "Program MKB" pada peningkatan kemampuan guru dalam mengelola kelas. Adapun hipotesis minor dalam penelitian ini adalah:

1. Ada pengaruh pelatihan "Program MKB" terhadap peningkatan kompetensi guru membangun kelas yang aman dan nyaman.

2. Ada pengaruh impelementasi "Program MKB" oleh guru dalam penurunan perilaku agresif siswa.

3. Ada pengaruh imlementasi "Program MKB" dalam peningkatan perilaku prososial siswa.

\section{METODE PENELITIAN}

\section{Subjek Penelitian}

Penelitian ini melibatkan kelompok eksperimen dan kelompok kontrol. Kedua kelompok berasal dari dua TK yang berbeda. Pemilihan dua TK yang berbeda sebagai kelompok kontrol dan kelompok eksperimen dalam penelitian ini ditujukan untuk menghindari bias karena seluruh guru kelas A (tahun pertama) pada kelompok eksperimen diberi pelatihan sehingga para guru tersebut memiliki kemampuan untuk melakukan implementasi program di kelas masingmasing. Kelompok eksperimen adalah kelompok guru yang diberi pelatihan "Program MKB" untuk kemudian akan diimplementasikan di kelas. Kelompok kontrol tidak mendapatkan perlakuan apapun. 


\section{Desain Penelitian}

Penelitian ini menggunakan disain penelitian eksperimen kuasi untreated control group design with pre-test and post-test. Sebelum program dimulai, guru kelas mendapat pelatihan singkat untuk menguasai program. Modul pelatihan dan modul program disusun berdasarkan manual The Anti Bullying and Teasing Program for Preschool Classsroom (Sprung, dkk., 2005).

\section{Pengukuran}

Dalam penelitian ini digunakan berbagai alat ukur untuk mengukur masingmasingvariabel penelitian. Untukmengukur kemampuan guru dalam mengelola kelas digunakan Skala Pengelolaan Kelas dan Panduan Observasi Pengelolaan Kelas. Panduan observasi perrforma guru, skala pengetahuan dan pemahaman guru, serta checklist adherence digunakan untuk mengukur kompetensi guru, catatan harian program untuk evaluasi pelaksanaan implementasi program. Untuk mengukur perilaku agresif siswa digunakan panduan observasi perilaku agresif, sedangkan untuk mengukur perilaku prososial siswa digunakan panduan observasi perilaku prososial.

\section{Prosedur Penelitian}

Persiapan Penelitian. Pada tahap persiapan penelitian, dilakukan beberapa kegiatan meliputi:

1. Meminta izin pada peneliti untuk melanjutkan kembali penelitian tentang Program MKB yang diadaptasi dari The-Anti-Bullying and Teasing for Preschool Classroom Community Theme dengan melaksanakan rekomendasi-rekomendasi dari peneliti sebelumnya.

2. Peneliti meminta izin pada sekolah yang akan dijadikan sebagai tempat penelitian dengan memberikan surat izin penelitian.

3. Meminta kesediaan guru dan orangtua untuk terlibat dalam penelitian dengan menandatangani informed consent dari peneliti.

4. Menyusun modul pelatihan dan modul program berdasarkan manual The-Anti-Bullying and Teasing program for Preschool Classroom dengan melakukan beberapa modifikasi untuk menyesuaikan dengan konteks sekolah. Modul untuk penelitian kali ini dilengkapi dengan aktivitas praktek berupa bermain peran agar guru dapat mencoba terlebih dahulu materi yang sudah mereka dapatkan dan melakukan evaluasi singkat terhadap pemahaman dan kemampuan guru dalam mengimplementasikan program. Selain itu, disusun pula rancangan surat untuk orangtua dan prosedur pemberiannya.

5. Menguji coba modul

6. Kegiatan ini dilaksanakan di TK di Sleman, yang setara dengan TK tempat melakukan penelitian, pada tanggal 28 Juni 2011. Uji coba modul dilaksanakan selama kurang lebih 4 jam dan diikuti oleh 8 orang guru. 
Sebelum pelatihan uji coba modul dimulai, para guru diberikan skala pengetahuan dan pemahaman guru dan setelah pelatihan selesai, skala kembali diberikan untuk mengetahui peningkatan pengetahuan yang terjadi setelah pelatihan.

7. Memberikan pembekalan atau coaching terhadap calon observer. Coaching observer sebanyak empat pertemuan yaitu 23 Juni 2011 dan dilanjutkan pada 6-8 Juli 2011. Saat coaching, para observer diberi pembekalan materi berupa teori mengelola kelas, kompetensi guru, perilaku agresif, dan perilaku prososial. Observer juga diberi penjelasan mengenai cara menggunakan panduan observasi, setiap aitem yang harus diamati dan cara pencatatannya dalam lembar panduan. Selain pembekalan materi, observer menggunakan panduan tersebut untuk mengobservasi perilaku guru dan siswa TK yang terekam dalam sebuah video yang harus diamati oleh observer selama dua kali. Pertama kali observer mengamati perilaku dan mencatat ke dalam panduan, kemudian peneliti dan observer membahas hasil observasi, untuk selanjutnya mencoba mengobservasi kembali video yang sama. Selain itu, observer juga diberikan tes tertulis mengenai pemahaman mereka terhadap penjelasan setiap item yang diamati dalam panduan observasi.
Pelaksanaan Penelitian. Berikut ini adalah beberapa kegiatan yang dilaksanakan ketika penelitian sudah mulai dilakukan:

1. Sebelum pelatihan ini dilaksanakan, pengambilan data prates dilakukan dengan meminta kesediaan guru untuk mengisi informed consent (lembar persetujuan) untuk terlibat dalam penelitian. Setelah menyatakan kesediaannya, guru-guru yang terlibat dalam penelitian ini diminta untuk mengisi skala kompetensi guru dan skala mengelola kelas yang diberikan pada 11 Agustus 2011. Pada 12-20 Juli 2011 peneliti melakukan observasi untuk mendapatkan data mengenai perilaku guru terkait dengan kemampuan mengelola kelas dan kompetensi guru saat mengajar di kelas. Observasi guru dilakukan di empat kelas, yaitu A1, A2, B1, dan B2, baik di TK kelompok eksperimen maupun TK kelompok kontrol dengan total jumlah guru di setiap sekolah adalah delapan orang. Selain guru, peneliti juga melakukan observasi terhadap para siswa di kelas A1 dan A2 di TK kelompok eksperimen dan kontrol untuk mengambil data perilaku agresif dan perilaku prososial siswa. Observasi dilakukan oleh para observer yang telah dilatih sebelumnya. Setelah mendapatkan data prates melalui serangkaian pengukuran, pada 23 Juli 2011 peneliti melaksanakan pelatihan program "MKB" 
pada guru TK yang telah menyetujui untuk berpartisipasi dalam pelatihan dengan memberikan persetujuan pada informed consent.

2. Pelatihan "MKB" semula direncanakan berlangsung dalam dua hari selama@ @ 3 jam. Berdasarkan ijin waktu yang diberikan oleh sekolah dan beberapa penyesuaian modul yang dilakukan oleh peneliti, pelatihan dilaksanakan dalam satu hari, selama 3 jam. Pelatihan Program MKB dilaksanakan pada 23 Juli 2011. Dalam pelatihan ini, guru aktif bertanya dan memberikan masukan terhadap pelaksanaan program yang akan diimplementasikan di kelas. Aktivitas bermain peran semula akan dilaksanakan dengan menggunakan pengkondisian, yaitu dua orang guru berperan sebagai pembawa materi dan guru lainnya menjadi siswa, namun berdasarkan masukan dari guru dan menyesuaikan dengan waktu pelatihan, aktivitas bermain peran dilakukan dengan cara guru mencoba memberikan instruksi dan menggunakan peralatan sesuai panduan pelaksanaan program.

3. Setelah pelatihan diberikan, guru diminta untuk mengisi kembali skala pengetahuan dan pemahaman guru untuk mengetahui perubahan yang terjadi pada pengetahuan dan pemahaman guru terhadap Program MKB sebagai data pascates.
4. Setelah mengikuti pelatihan Program MKB, guru diminta untuk mengimplementasikan program tersebut di dalam kelas. Implementasi program dilaksanakan selama tujuh hari, yaitu pada 25-29 Juli 2011 dan dilanjutkan pada 3-4 Agustus 2011. Saat implementasi program, para guru di setiap kelas diminta untuk menerapkan aktivitas untuk menciptakan kelas bersahabat sesuai dengan aktivitas yang direkomendasikan oleh program. Selama program diterapkan di kelas, setiap hari peneliti melakukan monitoring dengan mengobservasi perilaku guru untuk mengetahui kemampuan guru dalam menciptakan kelas yang aman dan nyaman sesuai dengan materi pelatihan dan panduan pelaksanaan program. Saat aktivitas belajar dan mengajar selesai, peneliti melakukan wawancara terhadap guru untuk mengevaluasi proses implementasi program. Peneliti menggunakan checklist adherence dan catatan harian pelaksanaan program sebagai alat untuk memonitor dan mencatat evaluasi pelaksanaan program setiap hari. Penjelasan pelaksanaan implementasi program di kelas terdapat pada Tabel 1 .

5. Setelah guru selesai menerapkan seluruh aktivitas program di kelas, peneliti mengambil data pascates perilaku agresif dan perilaku prososial. Pengukuran terhadap perilaku prososial 
dan perilaku agresif dilakukan dengan metode observasi. Observasi dilakukan dengan pendekatan time sampling dan metode pencatatan frekuensi (tally). Observasi dilakukan selama 30 menit saat kegiatan belajar berlangsung di kelas. Panduan observasi yang digunakan adalah panduan observasi perilaku prososial dan perilaku agresif. Pengambilan data pascates perilaku agresif dan prososial siswa dimulai pada 8-18 Agustus 2011.

\section{Teknik Analisis Data}

Analisis data dilaksanakan setelah peneliti mendapatkan seluruh data, baik prates maupun pascates dari kelompok eksperimen dan kontrol. Peneliti melihat pengaruh "Program MKB" pada kemampuan guru mengelola kelas dengan membandingkan hasil data prates dan pascates dengan uji-t pada kelompok eksperimen. Selain membandingkan hasil pada kelompok eksperimen, peneliti juga membandingkan hasil pascates antara kelompok ekperimen dan kelompok kontrol untuk mengetahui seberapa jauh "Program MKB" dapat memengaruhi kemampuan guru mengelola kelas pada kelompok eksperimen dan melihat perubahan kemampuan guru dalam mengelola kelas pada kelompok kontrol yang tidak diberikan pelatihan program. Data penelitian diolah menggunakan paired sample t-test dengan bantuan program SPSS. .

\section{HASIL PENELITIAN}

\section{Hasil Analisis Statistik}

Sebelum uji statistik untuk menguji hipotesis, terlebih dulu dilakukan uji statistik untuk membandingkan kondisi prates antara kelompok eksperimen dan kelompok kontrol. Hal ini dilakukan untuk memastikan bahwa kondisi prates kedua kelompok setara, sehingga bila data pascates kedua kelompok maka dapat dibuat simpulan bahwa terjadinya perubahan pada kelompok eksperimen memang disebabkan oleh perlakuan yang diberikan dan bukan karena faktor lain. Berikut ini akan disampaikan hasil uji statistik kondisi prates serta hasil uji statistik hipotesis penelitian untuk setiap variabel dalam penelitian payung ini.

Kemampuan Guru dalam Mengelola Kelas. Berdasarkan uji statistik diperoleh gambaran kondisi prates komponen pengetahuan kemampuan guru mengelola kelas pada kelompok eksperimen dan kelompok kontrol memiliki perbedaan rerata 0,04026, deviasi standar sebesar 0,2943 . Uji statistik tersebut diperoleh nilai t sebesar 1,008 dengan signifikansi sebesar 0,32 ( $p<0.05)$. Dapat disimpulkan bahwa saat prates pengetahuan guru dalam mengelola kelas pada kelompok eksperimen setara dengan kondisi pengetahuan guru dalam mengelola kelas pada kelompok kontrol.

Kondisi setara juga terjadi pada perbandingan keterampilan mengelola kelas yang diukur melalui observasi. 
Perbedaan rerata keterampilan mengelola kelas saat prates antara kelompok eksperimen dan kelompok kontrol adalah sebesar 1,625. Deviasi standar sebesar 0.24943 , nilai t yang diperoleh 2,030 dengan signifikansi sebesar 0,082 $(p<0,05)$.

Berdasarkan uji statistik terhadap pengetahuan dan keterampilan mengelola kelas guru saat prates dan pascates diketahui bahwa perbedaan rerata pengetahuan saat prates dan pascates adalah sebesar 38,125 dengan signifikansi sebesar $0,0001 \quad(p<0,05)$, sedangkan perbedaan keterampilan mengelola kelas saat prates dan pascates adalah sebesar 3,375 dengan signifikansi sebesar 0,002 $(p<0,05)$. Berdasarkan hasil uji statistik, Ho tidak dapat diterima sehingga dapat disimpulkan bahwa terdapat perbedaan skor pengetahuan dan keterampilan mengelola kelas guru saat prates dan pascates. Simpulan hasil statistik tersebut dapat dimaknai ada peningkatan kemampuan pengelolaan kelas guru pada kelompok eksperimen setelah pelatihan. Berikut ini adalah tabel hasil uji statistik untuk menguji perbedaan pengetahuan dan keterampilan guru dalam mengelola kelas.

Berikut ini adalah grafik perbedaan kondisi pengetahuan dan keterampilan guru dalam mengelola kelas guru pada saat prates dan pascates.

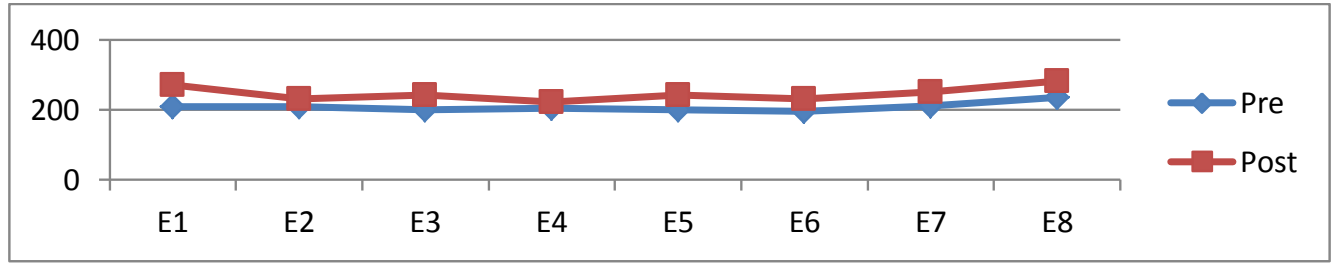

Gambar 1. Grafik perbedaan pengetahuan guru mengenai pengelolaan kelas pada saat prates dan pascates pada kelompok eksperimen.

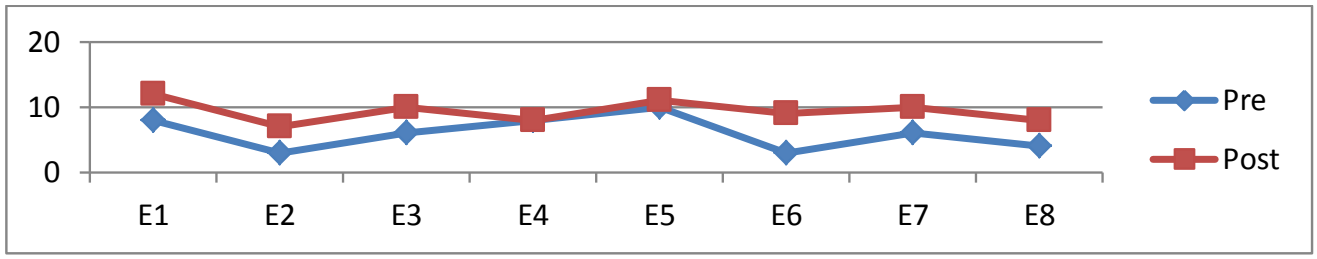

Gambar 2. Grafik perbedaan keterampilan guru mengenai pengelolaan kelas pada saat prates dan pascates pada kelompok eksperimen. 
Kompetensi guru dalam menciptakan kelas yang aman dan nyaman. Perbedaan rerata skala pengetahuan dan pemahaman guru pada kelompok eksperimen dan kelompok kontrol adalah sebesar 0,875 dengan deviasi standar sebesar 4,357. Besarnya nilai t pada perhitungan uji beda ini adalah sebesar 0,568 dengan nilai signifikansi $(p>0,05)$. Angka tersebut menunjukkan hipotesis Ho diterima atau tidak ada beda antara kondisi kelompok eksperimen dan kelompok kontrol sebelum pelatihan dilakukan.

Selain menguji data skala pengetahuan dan Pemahaman Guru, kompetensi guru dalam membangun kelas yang aman dan nyaman juga diukur dengan menggunakan metode observasi. Berdasarkan uji statistik yang dilakukan pada data observasi keterampilan guru dalam membangun kelas yang aman dan nyaman pada guru-guru, diperoleh hasil bahwa kelompok eksperimen memiliki kondisi yang setara dengan kelompok kontrol.

Hasil uji-t menunjukkan bahwa terdapat perbedaan rerata 0,75 dan nilai standar deviasi 1,035 antara kelompok eksperimen dan kelompok kontrol. Nilai uji-t menunjukkan angkan 2,049 dengan signifikansi 0,08 ( $p>0,05)$. Angka ini membuktikan hipotesis Ho diterima atau keterampilan guru kelompok kontrol setara dengan keterampilan guru kelompok eksperimen sebelum dilakukan pelatihan "Program MKB".
Setelah pelatihan "Program MKB" diberikan kepada guru-guru di TK kelompok eksperimen, kembali dilakukan pengambilan data dan dilakukan perhitungan statistik dengan bantuan SPSS untuk melakukan uji beda.

Perbedaan rerata antar kondisi adalah sebesar 36,625 dengan nilai standar deviasi sebesar 20,042. Sedangkan besarnya nilai $\mathrm{t}$ adalah 5,169 dengan signifikansi $0,001 \quad(p<0,05)$. Hasil tersebut menunjukkan bahwa terdapat peningkatan pengetahuan guru mengenai kelas yang aman dan nyaman setelah pelatihan program dilaksanakan.

Selain menguji data skala pengetahuan dan pemahaman guru, kompetensi guru dalam membangun kelas yang aman dan nyaman juga diukur dengan menggunakan metode observasi untuk mengukur keterampilan guru. Perbedaan rerata yang terjadi antara sebelum dan setelah pelatihan dilakukan adalah sebesar 2,75 dengan nilai standar deviasi sebesar 0,707. Nilai uji-t yang didapatkan sebesar 11,00 dengan nilai signifikansi $0,00(p<0,05)$. Angka tersebut menunjukkan bahwa ada beda antara kondisi sebelum dan sesudah pelatihan "Program MKB" pada keterampilan guru dalam membangun kelas yang aman dan nyaman. Perbedaan kondisi pengetahuan dan keterampilan guru dalam menciptakan kelas yang aman dan nyaman tampak dalam grafik 3 dan 4 . 


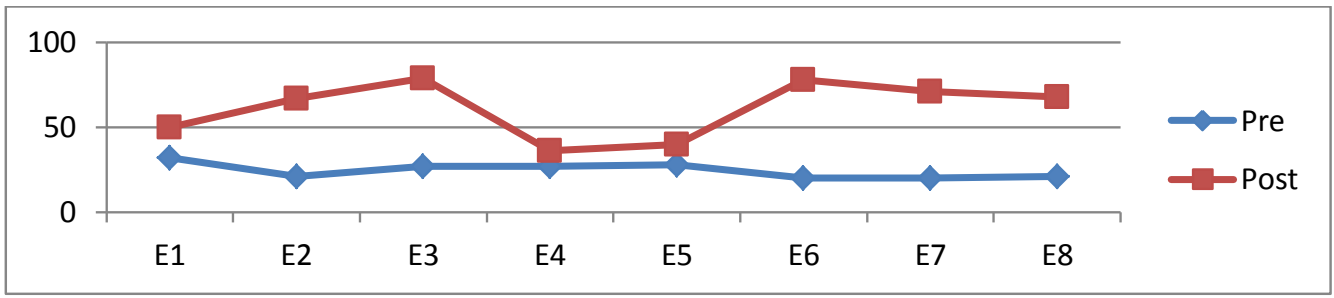

Gambar 3. Grafik perbedaan pengetahuan guru mengenai kelas yang aman dan nyaman saat prates dan pascates pada kelompok eksperimen.

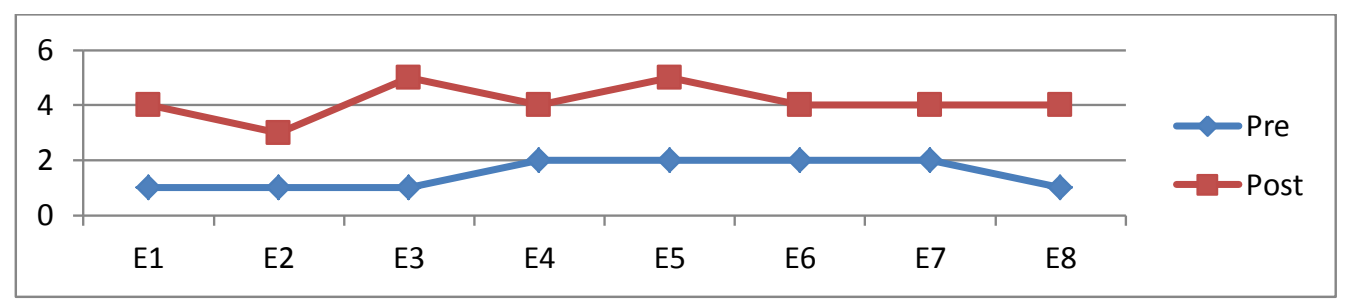

Gambar 4. Grafik perbedaan keterampilan guru mengenai kelas yang aman dan nyaman saat prates dan pascates pada kelompok eksperimen.

Perilaku Agresif Siswa. Peningkatan pengetahuan dan keterampilan mengelola kelas guru serta peningkatan kompetensi guru untuk menciptakan kelas yang aman dan nyaman juga selaras dengan perubahan perilaku siswa di kelas.

Uji beda kondisi perilaku agresif sebelum intervensi pada kelompok kontrol dan eksperimen menunjukkan nilai $\mathrm{t}$ sebesar 1.008 signifikansi perbedaan 0.32 $(p>0.005)$, perbedaan rerata sebesar 0,04026 dengan sd 0.24943. Dapat disimpulkan bahwa perilaku agresif siswa di kelompok eksperimen dan perilaku agresif siswa di kelompok kontrol adalah setara.

Berdasarkan hasil uji statistik, dapat dilihat bahwa perbedaan rerata antara kelompok eksperimen dan kelompok kontrol saat prates adalah 0,15179, dengan signifikansi perbedaan sebesar $0,93$ ( $p>0,05)$. Dengan demikian dapat disimpulkan bahwa perilaku prososial siswa kedua kelompok adalah setara ketika intervensi belum diberikan.

Hasilujistatistikyangmembandingkan kondisi kelompok eksperimen ketika saat prates dan pascates mendapatkan perbedaan rerata sebesar 0,26923 dengan signifikansi sebesar 0,000 $(p<0,05)$. Hasil tersebut menunjukkan bahwa terdapat peningkatan perilaku prososial pada kelompok eksperimen setelah intervensi diberikan. Grafik perbedaan frekuensi perilaku prososial siswa antara kondisi sebelum dan setelah intervensi pada kelompok eksperimen dapat dilihat pada grafik 6 . 


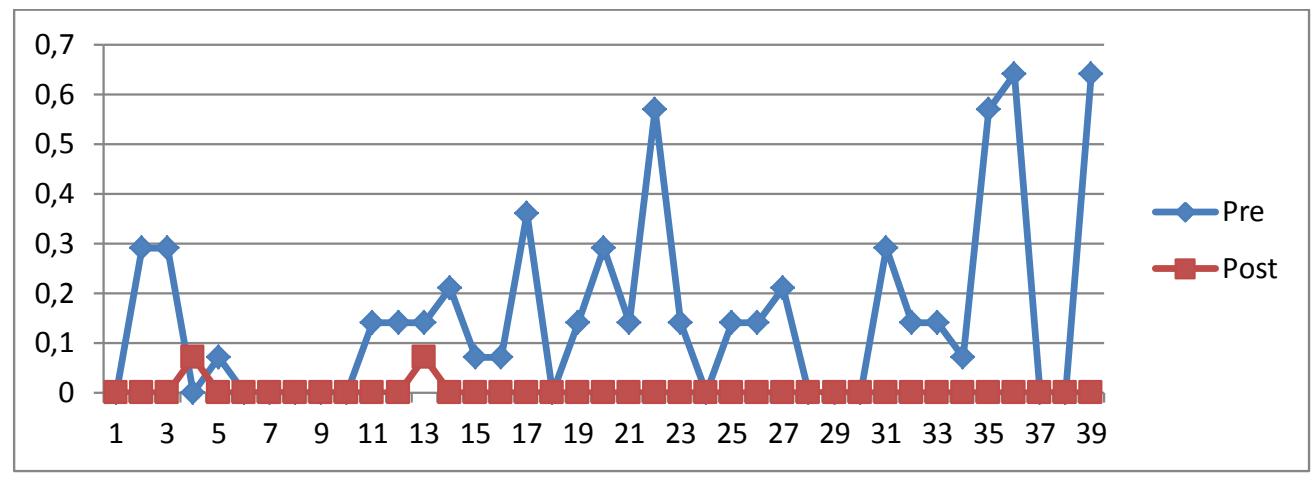

Gambar 5. Grafik perbedaan agresivitas pada masa saat prates dan pascates pada kelompok eksperimen.

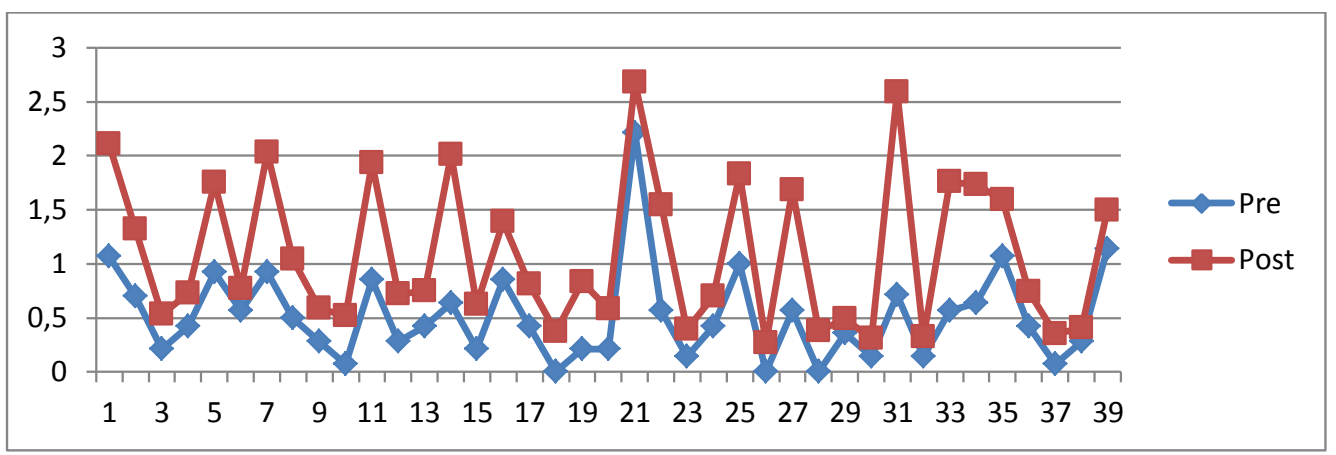

Grafik 6. Gambar perbedaan prososial pada masa sebelum dan setelah intervensi dalam kelompok eksperimen

Simpulan Hasil Penelitian. Perubahan yang terjadi pada guru setelah pelatihan dan pelaksanaan "Program MKB" dilakukan adalah guru menjadi mengerti dan memahami arti pentingnya menciptakan kelas bersahabat dengan menerapkan empat teladan guru, enam strategi kelas, dan tujuh aktivitas kelas. Selain itu, guru menjadi terampil untuk mengelola kelas dan menciptakan kelas yang aman dan nyaman yang ditunjukkan dengan guru semakin responsif ketika ada siswa yang kesulitan dengan melakukan
"Periksa" sesuai dengan rekomendasi program, menghentikan siswa yang berkonflik dan membantu siswa menyelesaikan masalah mereka di "Meja Ayo selesaikan", dan mengajak siswa yang sedang sedih atau murung pada "Sudut Menenangkan Diri".

Perubahan yang terjadi pada siswa adalah siswa menunjukkan sikap yang lebih tenang ketika pembelajaran di kelas dan dapat menghargai satu sama lain. Tujuh aktivitas kelas yang bertujuan untuk mengajarkan nilai-nilai mengenai 
berbagi dan bekerjasama ternyata dapat mengubah beberapa siswa yang pada awalnya terlihat individualistik, dan egois menjadi semakin ramah terhadap teman dengan menunjukkan kesediaannya untuk bekerjasama dan berbagi dengan teman di kelas. Selain itu, ketika sedang berkonflik, mereka dapat bernegosiasi untuk menyelesaikan masalah dan meminta maaf satu sama lain dengan guru sebagai mediator.

\section{PEMBAHASAN}

Hasil pengolahan data mendukung hipotesis mayor penelitian bahwa pelatihan Program MKB dapat meningkatkan kemampuan manajemen kelas guru TK. Pelatihan Program MKB disebut sebagai intervensi dalam penelitian ini. Berdasarkan analisis uji-t, dapat disimpulkan pengetahuan manajemen kelas guru pada TK kelompok eksperimen dan kelompok kontrol setara. Simpulan yang sama juga dapat ditarik dari analisis uji-t antara keterampilan (performance) manajemen kelas sebelum intervensi antara kelompok kontrol dan kelompok eksperimen. Hasil ini menandakan bahwa kondisi awal subjek pada kelompok kontrol dan kelompok eksperimen berada pada tingkat yang sama. Setelah pengukuran prates, guru-guru diberi pelatihan Program MKB kemudian mengimplementasikan di kelas masing-masing.

Pengukuran pascates dilakukan ketika guru mulai mengimplementasikan Program MKB di kelas. Hasil pengolahan data pascates menunjukkan terjadi perbedaan baik pada pengetahuan maupun keterampilan manajemen kelas guru di mana pengetahuan dan keterampilan manajemen kelas guru setelah pelatihan lebih tinggi dibandingkan kondisi sebelum pelatihan. Uji statistik menunjukkan kondisi yang serupa pada ketiga hipotesis minor pelatihan. Pengetahuan dan kompetensi guru meningkat setelah pelatihan, perilaku agresif siswa menurun setelah implementasi program, sedangkan perilaku prososial meningkat setelah guru mengimplementasikan program di kelas.

Ketujuh aktivitas dalam Program MKB merupakan aktivitas-aktivitas yang dirancang untuk dilaksanakan bersama oleh guru dan seluruh siswa dalam kelas sebagai kegiatan kolektif. Sudut pandang teori konstruktivisme sosial melihat proses belajar dan pembentukan perilaku anak sebagai pemaknaan atas stimulasi yang diperoleh dalam aktivitas bersama di kelas. Proses pemaknaaan melalui kegiatan bersama di kelas dipengaruhi faktorfaktor distribusi kerja kognitif, pengajaran timbal balik, menyuarakan gagasan, dan membahasakan pikiran (Palincsar, 1998). Guru memiliki peran sentral dalam menciptakan lingkungan kelas yang kondusif demi mendukung proses belajar bersama dan pembentukan perilaku para siswa melalui aktivitas-aktivitas kolektif kelas. Guru membutuhkan kemampuan pengelolaan kelas yang baik untuk dapat menjalankan peran sentral tersebut. 
Pengelolaan kelas adalah upaya guru untuk menciptakan lingkungan belajar yang sehat dan produktif di mana terjadi interaksi sosial yang positif di kelas, siswa memiliki motivasi belajar yang tinggi, tumbuh tanggung jawab untuk belajar, serta siswa dapat memaksimalkan waktu dan kesempatan untuk belajar (Eggen \& Kauchak, 2010; Burden 2003; Woolfolk, 2004). Untuk dapat menjalankan manajemen kelas yang baik, guru harus memperhatikan tujuh area manajemen kelas (Burden, 2003), yaitu (1) pentingnya memiliki suatu landasan filosofis dalam mengajar, (2) memilki pengaturan lingkungan fisik yang baik, (3) dapat mengatur perilaku siswa, (4) menciptakan lingkungan belajar yang saling mendukung dan saling menghormati, (5) mengatur dan memfasilitasi instruksi pengajaran, (6) menciptakan lingkungan kelas yang aman dan nyaman, serta (7) dapat berinteraksi dengan rekan guru lain/orangtua/pihak lain untuk mencapai tujuan pembelajaran. Berdasarkan ketujuh domain tersebut, konsep pengelolaan kelas dapat dimaknai memiliki dua bagian, yaitu sikap dan keyakinan guru mengenai pengelolaan kelas serta keterampilan praktis guru dalam mewujudkan sikap dan keyakinannya tersebut.

Pengelolaan kelas didefinisikan sebagai upaya guru untuk menciptakan lingkungan belajar yang sehat dan produktif. Lingkungan belajar yang sehat dan produktif hanya dapat dibangun ketika situasi kelas aman dan nyaman bagi siswa. Oleh karena itu, definisi ini mengandung makna bahwa guru harus mencapai sejumlah kompetensi menciptakan kelas yang aman dan nyaman sehingga upaya menciptakan lingkungan belajar yang kondusif di kelas dapat terwujud. Berdasarkan uji statistik terjadi kenaikan skor pengetahuan dan skor keterampilan pada kompetensi guru dalam menciptakan kelas yang aman dan nyaman. Kenaikan ini selaras dengan kenaikan skor skala dan skor keterampilan pengelolaan kelas. Hasil penelitian ini menggambarkan ketika kompetensi guru meningkat, maka pengelolaan kelas meningkat.

Guru yang berkompeten menciptakan kelas yang nyaman dan aman mampu mengajarkan pada siswa untuk berperilaku positif yang ditunjukkan dengan tidak adanya kekerasan yang dilakukan secara fisik maupun verbal (Burden, 2003). Implementasi Program Menciptakan Kelas Bersahabat memiliki dampak pada perilaku siswa di kelas. Hasil penelitian menunjukkan bahwa terjadi penurunan agresivitas siswa setelah implementasi program dilaksanakan. Penurunan ini terjadi selaras dengan peningkatan kompetensi guru. Kompetensi guru dalam menciptakan kelas yang nyaman dan aman tidak hanya menjamin berkurang atau menghilangnya kekerasan fisik dan verbal yang terjadi di kelas. Peningkatan kompetensi guru dalam melaksanakan Program MKB yang terwujud dalam implementasi empat teladan guru dan 
enam strategi kelas dalam pelaksanaan tujuh aktivitas juga tercermin dalam perubahan perilaku siswa di mana perilaku prososial siswa meningkat setelah implementasi program di kelas oleh guru. Gambaran perubahan situasi guru dan siswa dapat dipahami melaui teori mikrosistem Bronfenbrenner (Berns, 2007). Guru dan orangtua merupakan bagian mikrosistem tumbuh kembang anak usia dini. Anak usia dini membutuhkan perlakuan yang konsisten antara perlakuan orangtua di rumah dengan perlakuan guru di sekolah. Untuk membantu diperolehnya konsistensi perlakuan dalam implementasi program peneliti, menggunakan buku penghubung implementasi program. Selama pelaksanaan tujuh aktivitas program di kelas orangtua aktif mengisi buku penghubung sesuai rekomendasi aktivitas di rumah yang ada dalam buku penghubung. Dalam buku penghubung tersebut orangtua juga memberikan saran untuk memodifikasi aktivitas-aktivitas di rumah sesuai dengan kondisi anak.

Dalam penelitian ini terdapat halhal yang mendukung proses pelaksanaan pelatihan dan implementasi program, yaitu:

1. Situasi budaya lingkungan sekolah yang terbuka dan antusias terhadap program yang dibawa peneliti. Keterbukaan pihak sekolah ini mendukung implementasi prosedur program oleh guru dapat dilaksanakan dengan baik sesuai tahapan dalam modul yang dilatihkan.
2. Situasi lingkungan fisik sekolah yang fleksibel untuk, serta harapan guru terhadap perilaku/capaian siswa.

Selain itu, terdapat beberapa hal yang menjadi keterbatasan dalam penelitian ini, yaitu:

1. Terbatasnya waktu pelatihan yang diberikan sekolah sehingga peneliti harus memodifikasi rundown acara dan membagikan materi secara tertulis untuk mengefektifkan waktu penyamapaian materi.

2. Kesulitan guru memilih waktu untuk pelaksanaan beberapa aktivitas. Waktu yang dipilih, misalnya ketika persiapan sholat untuk aktivitas "Persamaan dan Perbedaan". Semula waktu ini dipilih dengan pertimbangan waktu aktivitas lebih santai, tetapi pilihan yang dibuat guru ini ternyata membuat pelaksanaan aktivitas di salah satu kelas berlangsung kurang antusias karena murid-murid sudah mengantuk.

3. Keterbatasan peneliti untuk mengukur keterlibatan orangtua dalam implementasi Program MKB serta perlakuan orangtua terhadap anak di rumah. Keterbatasan ini terjadi karena fokus implementasi program adalah pada setting sekolah. Buku penghubung yang peneliti berikan tidak ditujukan untuk mengukur maupun mengkontrol perlakuan orangtua di rumah kepada anak. Buku ini berisi informasi aktivitas yang dilakukan 
di sekolah serta rekomendasi aktivitas yang dapat dilakukan orangtua di rumah untuk mendukung implementasi program di sekolah.

\section{SIMPULAN DAN SARAN}

\section{Simpulan}

Penelitian menunjukkan bahwa pelatihan pada guru mengenai Program MKB dapat meningkatkan kemampuan guru dalam mengelola kelas dan kompetensi guru dalam menciptakan kelas yang aman dan nyaman. Selanjutnya, implementasi Program MKB oleh guru di kelas TK dapat menurunkan perilaku agresif dan meningkatkan perilaku prososial siswa di kelas tersebut.

\section{Saran}

Beberapa hal yang disarankan untuk dilakukan untuk pengembangan program dan penelitian lanjutan adalah:

1. Mengembangkan modul dan program dengan mengadaptasi tematema yang ada dalam buku The Anti Bullying and Teasing Classroom setelah tema Komunitas, yaitu tema Perasaan, tema Persahabatan, dan tema Teasing and Bullying, karena program MKB baru mengadaptasi tema komunitas, yaitu tema pertama dalam buku tersebut

2. Modifikasi terhadap modul atau program hendaknya disesuaikan dengan kondisi dan kultur sekolah berdasar- kan persetujuan penulis buku The Anti Bullying and Teasing for Preschool Classroom.

3. Bila akan ada penelitian lanjutan, hendaknya diperhatikan kembali faktor-faktor eksternal yang dapat memengaruhi hasil penelitian, seperti melakukan kontrol terhadap status sosial ekonomi dan pendidikan orangtua siswa yang menjadi subjek penelitian.

\section{DAFTAR PUSTAKA}

Barboza, G.E., Schiamberg, L.B., Oehmke, J., Korzeniewski, S.J., Post, L.Al, \& Heraux, C.G. (2009). Individual characteristics and the multiple contexts of adolescent bullying: An ecological perspective. J Youth Adolescence, 38, 101 - 121.

Berns, R.M. (2007). Child, Family, School, Community: Socialization and Support. New York : Thomson Learning, Inc.

Bronfenbrenner, U., \& Evans, G.W. (2000). Developmental Science in the $21^{\text {st }}$ Century: Emerging Questions, Theoretical Models, Research Designs and Empirical Findings. Social Development, 9 (1), 115-125.

Burden, P.R. (2003). Classroom Management: Creating a Successful Learning Community. New York: John Wiley Inc 
Carlo, G. \& Randall, B.A. (2002). The Development of a Measure of Prosocial Behaviors for Late Adolescents. Journal of Youth and Adolescence, 31(1), 31-44.

Eggen, P. \& Kauchak, D. (2010). Educational Psychology: Windows on Classroom. New Jersey: Pearson Education Inc.

Ferguson, C.J., Miguel, C.S., Kilburn, J.C., \& Sanchez, P. (2007). The Effectiveness of School-Based AntiBullying Programs: a Meta-Analytic Review. Criminal Justice Review, 32 (4), 401-414.

Kumara, A., Winahyu, G.S., Dara, Y.P., Dinardinata, A. (2010a). Studi Pendahuluan Survei Perilaku Sosial Siswa. Tidak diterbitkan. Yogyakarta: Fakultas Psikologi Universitas Gadjah Mada Yogyakart. Yogyakarta: Fakultas Psikologi UGM

Kumara, A., Dinardinata, D., Winahyu, G.S., \& Dara, Y.P. (2010b). Efektivitas Program The Anti Bullying and Teasing Program for Preschool Classroom Dalam Meningkatkan Kualitas Iklim Kelas di Taman KanakKanak. Naskah Publikasi (in process).

Moore, K.D., (2003). Classroom Teaching Skills. Boston: McGraw Hill.

Olweus, D. (1993). Bullying at School: What We Know and What We Can Do. Cambridge, MA: Blackwell.
Ormrod, J.E. (2006). Educational Psychology: Developing Learners. Upper Saddle River: Pearson Merrill Prentice Hall.

Palincsar, A.S. (1998). Social Constractivist Perspectives on Teaching and Learning. Annual Reviews Psychology, 49, 345-375.

Papalia, D.E, Olds, S.W, Feldman, R.D, Gross, D. (2004). Human Development $9^{\text {th }}$ Edition. New York: McGraw-Hill.

Perren, S. (2000). Kindergarten Children Involved In Bullying: Social Behavior, Peer Relationships, and Social Status. Disertasi, tidak dipublikasikan. Philosophisch-historischen Fakultät der Universität Bern, Selbstverlag-Basel.

Sprung, B., Froschl, M., \& Hinitz, B. (2005). The Anti-Bullying and Teasing Book for Preschool Classrooms. Beltsville: Gryphon House, Inc.

Steedly, K.M., Schwartz, A., Levin, M., Luke, S.D. (2008). Social Skills and Academic Achievement. Evidence for Education, 3(2).

Storey, K.S., \& Slaby, R. (2008). Eyes on Bullying: What Can You Do?: a Toolkit to Prevent Bullying in Children's Life. Newton: Education Development Centre Inc. 